\title{
Genetic Diversity Analysis Revealed the Hot Spot of Acmella Paniculata Existing in Natural Populations of Gujarat
}

\section{Sveta Patel}

Gujarat University

Nikisha Purohit

Gujarat University

\section{Palak Sapra}

Gujarat University

Hitesh Solanki

Gujarat University

Ashok Kumar Bishoyi ( $\square$ ashokkumar.bishoyi@marwadieducation.edu.in )

Marwadi University https://orcid.org/0000-0001-6810-2511

\section{Research Article}

Keywords: Biodiversity, Barcoding, Genotype, Genetic diversity, ISSR marker

Posted Date: January 31st, 2022

DOI: https://doi.org/10.21203/rs.3.rs-1238957/v1

License: @ (i) This work is licensed under a Creative Commons Attribution 4.0 International License. Read Full License 


\section{Abstract}

Genetic diversity analysis contributes to the conservation, protection and utilization of genetic resources toward efficient management of germplasm. In this investigation, Inter Simple Sequence Repeats (ISSR) markers were used to analyze the genetic diversity of 32 genotypes of Acmella paniculata collected from 12 different states of Gujarat, India. There were 113 loci amplified by 15 different ISSR markers with an average of 7.53 loci per primer. From the total 113 amplicons; 81 were polymorphic, 43 were monomorphic and 9 were found to be unique showing an average of $60.18 \%$ polymorphism. The primer $(\mathrm{CT})_{8} \mathrm{~T}$ produced a high value (0.65) of polymorphic information content (PIC); whereas, primer (TC) 8 RA produced a low value (0.21). The resolving power (RP) value of the primers ranged from 5.25 in primer (TC) ${ }_{8} R A$ to 23.19 in primer $(\mathrm{AC})_{8} \mathrm{YT}$ with an average of 12.17 . The Jaccard's similarity coefficients value ranged from 0.48 to 0.94 . The highest percentage of similarity (94\%) was found between accessions AP6 and AP16 which were collected from Panchmahal and Narmada respectively, as they are geographically closely located. Whereas, accessions AP2 from Banaskantha and AP7 from Panchmahal were most distantly related with the similarity value of $48 \%$, as expected to their collection locations. The study revealed that there is no correlation between geographical distance and genetic diversity among the populations studied. The resultant data generated from ISSR molecular marker-based genetic diversity analysis of $A$. paniculata in Gujarat can provide a reference for the conservation and efficient management of the important Indian genetic resources.

\section{Introduction}

Acmella paniculata (Wall Ex. DC.) R. K. Jansen is commonly known as the "Toothache Plant" because of its wide use to cure toothache and gum infection. The genus Acmella (Spilanthes) has more than 30 species, generally occurring in the tropics and subtropical parts of the world (Reshmi et al. 2016). In India, it is distributed in Andhra Pradesh, Assam, Chattisgarh, Goa, Gujarat, Himachal Pradesh, Kerala, Karnataka, Meghalaya, Maharastra, Madhya Pradesh, Rajasthan, and Tamil Nadu (Cook 1996). The species possesses a wide range of phytoconstituents such as alkaloids, tannins, saponins, and flavonoids (Mamidala and Gujjeti 2013; Rajeshwar and Lalitha 2013). Acmella paniculata known to possess a vast range of pharmacological activities like antimicrobial (Arora et al. 2011; Sharma et al. 2012), antioxidant (Sana et al. 2014), anti-inflammatory (Urankar et al. 2013), insecticidal (Borges-Del-Castillo et al. 1984), antipyretic, antiulcer \& anticancer (Paulraj et al. 2013), a local anesthetic (Chakraborty et al. 2002), larvicidal (Saraf and Dixit 2002), etc. The plant has a great source of spilanthol (alkylamides); the principal bioactive compound which has been used as medicine to cure bacterial and fungal infections, rheumatism, urinary tract infection, kidney and gall stone pulverization, cancer, etc (Patel et al. 2019).

Medicinal plants face a high risk of genetic diversity erosion due to their destructive collecting patterns from the wild. In this situation, it is essential to catalog the medicinal plant resources and maintain their germplasm through various strategies. Evaluation of genetic diversity using molecular markers aids in realistic conservation \& crop improvement strategies and helps in deciding which germplasm to conserve on a priority basis (Morikawa and Leggett 1990; Nybom and Bartish 2000; Bishoyi et al. 2014). A better understanding of genetic diversity and its distribution in the natural population is essential for plant conservation and its efficient utilization towards human welfare (Morikawa and Leggett 1990; Bishoyi et al. 2016a; Bishoyi et al. 2018).

In India; six species are reported from the genus Acmella are, $A$. ciliata, $A$. oleracea, $A$. paniculata, $A$. radicans, $A$. uliginosa and $A$. calva. Identification of these species becomes confusing because of more or less similar morphological characteristics and these are highly influenced by the environmental modulations. In this investigation, two species of Acmella have been taken for identification and genetic diversity analysis. The traditional identification method becomes less effective for $A$. paniculata and $A$. radicans because of similarities in morphological features except for flower color (the white color flower is $A$. paniculata and the yellow flower colour is $A$ radicans), flowering season, and its habitat. Hence 
we opted for the DNA barcoding technique; which has been proved as a more reliable, authenticate and accurate tool for the identification of an organism (Kress et al. 2007; Hebert et al. 2009; Bishoyi et al. 2017; Li et al. 2021)

Molecular markers are employed to assess genetic diversity which will reveal the distribution and extent of genetic variation within the species (Nybom and Bartish 2000). DNA-based molecular markers are the best choice for accurately assessing genetic diversity among the population (Bishoyi et al. 2018; Nadeem et al. 2018). Although a large number of molecular marker techniques exist, each marker technique has its strengths and weaknesses (Powell et al. 1996). Randomly Amplified Polymorphic DNA (RAPD) and Inter Simple Sequence Repeats (ISSR) are basic approaches used for molecular authentication and validation as they are faster, cheaper and require no prior information of DNA sequence (Bishoyi et al. 2016; Gupta et al. 2017). Genetic diversity evaluation of Acmella paniculata populations from Gujarat state has not been recorded yet. Hence, the present study aims to evaluate the genetic diversity analysis of $A$. paniculata using ISSR markers collected from different regions of Gujarat State. Due to the lack of DNA sequence information of $A$. paniculata, in the present investigation; ISSRs make a perfect choice for carrying forward the investigation.

\section{Materials And Methods Plant Material Collection:}

Five samples of each Acmella paniculata and Acmella radicans were collected from Navsari and Sabarkantha district, Gujarat respectively. Both the species were morphologically identified at the Department of Botany, Gujarat University and processed for DNA barcoding experiments.

Around 90 plant samples of Acmella paniculata (Wall ex. DC) R. K. Jansen was collected from various locations of 12 districts of Gujarat. All samples were identified at the Department of Botany, Gujarat University. Freshly collected healthy and tender young leaves were wiped with ethanol to assure contamination-free specimen collection. The leaves were stored in a plastic bag filled with silica gel and tagged with sample ID. The specimens were stored in $-20^{\circ} \mathrm{C}$ for further utilization. Voucher specimen has been made for future reference and submitted to the department of botany herbarium. From the above samples, 32 samples representing each and all populations were taken for DNA isolation followed by genetic diversity analysis. Details of the sample collection, locations with passport data are given in Figure 1 \& Table 1 . The species are surveyed throughout the Gujarat, but it was available at the river side of some districts as shown in Figure 1 \& Table 1. 
Table 1

Details of populations of $A$. paniculata collected from different locations of Gujarat

\begin{tabular}{|c|c|c|c|}
\hline Sample No. & Sample ID & District & Location \\
\hline 1 & AP1 & \multirow[t]{2}{*}{ Banaskantha } & $24^{\circ} 17^{\prime} 39.87^{\prime \prime N} 72^{\circ} 37^{\prime} 22.93^{\prime \prime E}$ \\
\hline 2 & AP2 & & $24^{\circ} 20^{\prime} 08.87^{\prime \prime} \mathrm{N} 72^{\circ} 52^{\prime} 50.07^{\prime \prime} \mathrm{E}$ \\
\hline 3 & AP3 & \multirow[t]{2}{*}{ Sabarkantha } & $23^{\circ} 35^{\prime} 10.70^{\prime \prime N} 72^{\circ} 57^{\prime} 10.80^{\prime \prime E}$ \\
\hline 4 & AP4 & & $24^{\circ} 00^{\prime} 24.27^{\prime \prime N} 73^{\circ} 26^{\prime} 92.70^{\prime \prime E}$ \\
\hline 5 & AP5 & \multirow[t]{4}{*}{ Panchmahal } & $22^{\circ} 68^{\prime} 39.68^{\prime \prime} \mathrm{N} 73^{\circ} 71^{\prime} 54.10^{\prime \prime E}$ \\
\hline 6 & AP6 & & $22^{\circ} 70^{\prime} 42.55^{\prime \prime} \mathrm{N} 73^{\circ} 77^{\prime} 04.94 " \mathrm{E}$ \\
\hline 7 & AP7 & & $22^{\circ} 35^{\prime} 05.39^{\prime \prime N} 73^{\circ} 70^{\prime} 50.67^{\prime \prime E}$ \\
\hline 8 & AP8 & & $22^{\circ} 40^{\prime} 24.44^{\prime \prime} \mathrm{N} 73^{\circ} 64^{\prime} 88.71^{\prime \prime} \mathrm{E}$ \\
\hline 9 & AP9 & \multirow[t]{2}{*}{ Dahod } & $22^{\circ} 68^{\prime} 78.92^{\prime \prime} \mathrm{N} 73^{\circ} 90^{\prime} 17.12 " \mathrm{E}$ \\
\hline 10 & AP10 & & $22^{\circ} 61^{\prime} 15.42 " \mathrm{~N} 73^{\circ} 96^{\prime} 38.81^{\prime \prime E}$ \\
\hline 11 & AP11 & \multirow[t]{2}{*}{ Chotaudepur } & $22^{\circ} 34^{\prime} 98.74^{\prime \prime} \mathrm{N} 74^{\circ} 05^{\prime} 84.35^{\prime \prime} \mathrm{E}$ \\
\hline 12 & AP12 & & $22^{\circ} 30^{\prime} 21.17 " \mathrm{~N} 73^{\circ} 99^{\prime} 10.03^{\prime \prime E}$ \\
\hline 13 & AP13 & \multirow[t]{5}{*}{ Narmada } & $21^{\circ} 60^{\prime} 30.29^{\prime \prime} \mathrm{N} 73^{\circ} 49^{\prime} 31.15^{\prime \prime} \mathrm{E}$ \\
\hline 14 & AP14 & & $21^{\circ} 51^{\prime} 93.30 " \mathrm{~N} 73^{\circ} 35^{\prime} 63.86 " \mathrm{E}$ \\
\hline 15 & AP15 & & $21^{\circ} 86^{\prime} 36.44^{\prime \prime} \mathrm{N} 73^{\circ} 63^{\prime} 55.17^{\prime \prime E}$ \\
\hline 16 & AP16 & & $21^{\circ} 51^{\prime} 52.81^{\prime \prime} \mathrm{N} 73^{\circ} 64^{\prime} 01.52 " \mathrm{E}$ \\
\hline 17 & AP17 & & $21^{\circ} 57^{\prime} 70.63^{\prime \prime N} 73^{\circ} 68^{\prime} 06.83^{\prime \prime E}$ \\
\hline 18 & AP18 & \multirow[t]{2}{*}{ Bharuch } & $21^{\circ} 63^{\prime} 51.24 " \mathrm{~N} 73^{\circ} 36^{\prime} 59.29 " \mathrm{E}$ \\
\hline 19 & AP19 & & $21^{\circ} 58^{\prime} 30.44^{\prime \prime} \mathrm{N} 73^{\circ} 35^{\prime} 54.65^{\prime \prime} \mathrm{E}$ \\
\hline 20 & AP20 & \multirow[t]{2}{*}{ Surat } & $21^{\circ} 38^{\prime} 67.70^{\prime \prime N} 73^{\circ} 32^{\prime} 97.03^{\prime \prime E}$ \\
\hline 21 & AP21 & & $21^{\circ} 44^{\prime} 85.81^{\prime \prime} \mathrm{N} 73^{\circ} 32^{\prime} 02.41^{\prime \prime E}$ \\
\hline 22 & AP22 & \multirow[t]{4}{*}{ Tapi } & $21^{\circ} 05^{\prime} 26.27^{\prime \prime} \mathrm{N} 73^{\circ} 23^{\prime} 59.63^{\prime \prime E}$ \\
\hline 23 & AP23 & & $21^{\circ} 15^{\prime} 04.8^{\prime \prime N} 73^{\circ} 22^{\prime} 40.7^{\prime \prime E}$ \\
\hline 24 & AP24 & & $20^{\circ} 58^{\prime} 38.7^{\prime \prime} \mathrm{N} 73^{\circ} 37^{\prime} 24.8^{\prime \prime} \mathrm{E}$ \\
\hline 25 & AP25 & & $20^{\circ} 58^{\prime} 11.8^{\prime \prime} \mathrm{N} 73^{\circ} 29^{\prime} 18.4^{\prime \prime} \mathrm{E}$ \\
\hline 26 & AP26 & \multirow[t]{2}{*}{ Dang } & $20^{\circ} 54^{\prime} 06.0^{\prime \prime} \mathrm{N} 73^{\circ} 35^{\prime} 26.0^{\prime \prime} \mathrm{E}$ \\
\hline 27 & AP27 & & $20^{\circ} 48^{\prime} 21.26^{\prime \prime} \mathrm{N} 73^{\circ} 34^{\prime} 04.37^{\prime \prime} \mathrm{E}$ \\
\hline
\end{tabular}




\begin{tabular}{|llll|}
\hline Sample No. & Sample ID & District & Location \\
\hline 28 & AP28 & & $20^{\circ} 58^{\prime} 01.9^{\prime \prime} \mathrm{N} 73^{\circ} 29^{\prime} 36.6^{\prime \prime} \mathrm{E}$ \\
\hline 29 & AP29 & Valsad & $20^{\circ} 59^{\prime} 38.17^{\prime \prime} \mathrm{N} 73^{\circ} 23^{\prime} 51.999^{\prime \prime} \mathrm{E}$ \\
\hline 30 & AP30 & & $20^{\circ} 34^{\prime} 76.29^{\prime \prime} \mathrm{N} 72^{\circ} 98^{\prime} 95.52^{\prime \prime} \mathrm{E}$ \\
\hline 31 & AP31 & & $20^{\circ} 52^{\prime} 56.43^{\prime \prime} \mathrm{N} 73^{\circ} 17^{\prime} 79.68^{\prime \prime} \mathrm{E}$ \\
\hline 32 & AP32 & Navsari & $20^{\circ} 46^{\prime} 31.5^{\prime \prime} \mathrm{N} 73^{\circ} 21^{\prime} 51.4^{\prime \prime} \mathrm{E}$ \\
\hline
\end{tabular}

\section{Genomic Dna Extraction:}

The collected leaves were ground to fine powder in mortar and pestle using liquid nitrogen. DNA extraction was carried out according to the modified CTAB protocol of Bishoyi et al. (2016b). The quality of DNA was checked by performing on $0.8 \%$ agarose gel electrophoresis. Quantification of DNA was done with a BioTek ${ }^{T M}$ Epoch $^{T M}$ Microplate Spectrophotometer (US). Isolated DNA was stored in $-80^{\circ} \mathrm{C}$ temperatures for further usage in the polymerase chain reaction.

\section{Barcode Gene Amplification And Sequencing:}

Universal $r b c /$ primers ( $r b c / 1 F \&$ rbc/724R) reported by Fay et al. (1998) were taken for barcode gene amplification. PCR reactions were carried out in $25 \mu$ volumes containing $40 \mathrm{ng}$ of template DNA, $2 \mu \mathrm{m}$ of each of the four dNTPs, 1X PCR buffer (10 mm Tris, $50 \mathrm{~mm} \mathrm{KCl),} 1.5 \mathrm{~mm} \mathrm{MgCl} 2$, 1 unit Taq DNA polymerase and 10 picomols of each primer. PCR profile was kept at initial denaturation at $95^{\circ} \mathrm{C}$ for 5 mins followed by 35 cycles of $95^{\circ} \mathrm{C}$ for $30 \mathrm{sec}$, annealing at $50^{\circ} \mathrm{C}$ for 30 sec and strand extension at $72^{\circ} \mathrm{C}$ for $1 \mathrm{~min}$, followed by final extension $72^{\circ} \mathrm{C}$ for $10 \mathrm{~min}$. PCR amplification was carried out in Veriti Thermal Cycler (Applied Biosystems, US). The amplified PCR products were sequenced using the BigDye Terminator V3.1 cycle sequencing kit according to the provided protocol. Cycle sequencing reaction mixture consisted of $4 \mu$ of Terminator ready reaction mix, 120-300 ng of the amplicon, 10 picomols of primer, $1 \mu \mathrm{l}$ of Big dye sequencing buffer and deionized water to make the volume up to $10 \mu \mathrm{l}$. Two individual reaction tubes were prepared for forward and reverse primers. PCR amplification was carried out in Veriti Thermal Cycler (Applied Biosystems, US). Cycle sequencing conditions were kept at 4 min at $96 \mathrm{C}$; followed by 25 cycles of $10 \mathrm{sec}$ at $96 \mathrm{C}, 5 \mathrm{sec}$ at $55 \mathrm{C}, 4$ min at 60 C, and 4 C for infinity time. Cycle sequencing purification was done using Big Dye Terminator purification kit by following provided instructions. Sequencing of DNA was done using 3500XL Genetic Analyzer (Applied Biosystems, US). Codoncode aligner 5.0.2 was used for sequence assembly, alignment and contig preparation. Resulted sequences were further analyzed in National Center for Biotechnology Information (NCBI) blast and submitted in the NCBI gene bank \& Barcode of Life Data System (BOLD system) for public access.

\section{Issr -pcr Analysis:}

Fifty-five synthesized Inter Simple Sequence Repeats primers (synthesized from Xcleris, Ahmedabad) were taken for initial screening. Optimum amplification conditions and their annealing temperature were standardized with the help of gradient PCR. Out of 55 primers taken, 15 primers were selected for further analysis due to the generation of clear and reproducible amplification. The DNA amplification protocol was carried out by following the procedure of Zeitkiewicz et al (1994) with suitable modifications. Each PCR amplification was carried out with $25 \mu$ reaction mixture containing $2.5 \mu$ l of $10 \mathrm{X}$ Taq buffer having $\left(\mathrm{NH}_{4}\right)_{2} \mathrm{SO}_{4}$ (Thermo scientific, USA), $2 \mu \mathrm{l}$ of $\mathrm{MgCl}_{2}(25 \mathrm{mM}), 0.3 \mu \mathrm{l}$ of $10 \mathrm{mM}$ dNTPs (Thermo scientific, USA), $0.3 \mu \mathrm{l}$ of Taq polymerase ( $5 \mathrm{U} / \mu \mathrm{l}$; Thermo Scientific, USA), $1.5 \mu \mathrm{l}$ of primer $(10 \mathrm{pmol} / \mu \mathrm{l}), 2 \mu \mathrm{l}$ of genomic DNA (50 ng) and 
final volume was made up with $\mathrm{ddH}_{2} \mathrm{O}$. PCR reactions were carried out in the Veriti ${ }^{\mathrm{TM}}$ Thermal Cycler (Applied Biosystems, US) with optimum amplification conditions. To perform ISSR amplification; PCR condition consisted of denaturation at $94^{\circ}$ $\mathrm{C}$ for 5 mins, 35 cycles at $94^{\circ} \mathrm{C}$ for 1.30 mins, annealing was optimized according to the primer for 1.30 mins and extension at $72^{\circ} \mathrm{C}$ for 2 mins, followed by a final extension at $72^{\circ} \mathrm{C}$ for 10 mins. Amplified products were stored at $4^{\circ} \mathrm{C}$ until they were subjected to gel electrophoresis. The reproducibility of DNA profiles was examined by repeating twice all the PCR amplification with each selected individual primers. Only reproducible bands were considered for further analysis. Negative control was incorporated in all PCR reactions to check the cross-contamination of the samples.

\section{Agarose Gel Electrophoresis:}

PCR products of the DNAs were separated by using 1.5\% gel agarose electrophoresis (Genei Banglore, India) containing ethidium bromide (SRL) in 1X TBE buffer (40 mM tris base, $20 \mathrm{mM}$ boric acid, $1 \mathrm{mM}$ EDTA) at $100 \mathrm{~V}$ for $80 \mathrm{mins} .100 \mathrm{bp}$ DNA ladder (Thermo Fisher Scientific, US) was run alongside PCR products to determine the molecular weight of amplified products. Ethidium bromide-stained gels were documented by using the UVITEK (Cleaver Scientific, UK), gel documentation system.

\section{Data Analysis:}

Gel images were used to score data for ISSR markers. Each DNA amplicon given by primer was considered as a unit character and the fragments were scored as a binary variable $(1,0)$ for presence and absence, respectively. Documentation of the total no of bands, monomorphic bands, polymorphic bands and Unique bands has been done from the binary data matrix box. Data were analyzed by NTSYS 2.02 software (Rohlf 1998). Jaccard's coefficient similarity was calculated using the SIMQUAL (Similarity for quantitative data) program (Jaccard 1908). A dendrogram was constructed based on UPGMA (Unweighted Pair Group Method using Arithmetic average) and SAHN (Sequential agglomerative hierarchical Nonoverlapping) clustering. RP value (Resolving Power) of the primers was calculated as per Prevost and Wilkinson (1999) formula. Marker index of each primer was also calculated according to Powell et al (1996) and Polymorphic information content (PIC) was determined with the formula given by Anderson et al (1993).

\section{Results And Discussion Barcode gene amplification and sequencing:}

The present investigation was able to accurately sequence $707 \mathrm{bp}$ and $723 \mathrm{bp}$ of the $\mathrm{rbc/gene}$ for Acmella paniculata and Acmella radicans, respectively. Species identification has been confirmed in NCBI- BLAST which shows 99-100\% homology with $99 \%$ query cover. More details of the barcode analysis are shown in Table 2 . In this investigation, $r b c /$ alone was able to identify both the studied species; which has been recently proved by similar studies across different parts of the globe (Enan et al. 2017; Chandrasekara et al. 2021; Ho et al. 2021; Li et al. 2021). 
Table 2

Details of the barcode gene sequencing

\begin{tabular}{|c|c|c|c|c|c|c|c|}
\hline $\begin{array}{l}\text { SI } \\
\text { No }\end{array}$ & $\begin{array}{l}\text { Name of the } \\
\text { gene }\end{array}$ & $\begin{array}{l}\text { Nucleotide } \\
\text { length }\end{array}$ & $\begin{array}{l}\text { Query } \\
\text { cover }\end{array}$ & $\begin{array}{l}\% \\
\text { Identity }\end{array}$ & $\begin{array}{l}\mathrm{E} \\
\text { value }\end{array}$ & $\begin{array}{l}\text { Name of the } \\
\text { plant }\end{array}$ & $\begin{array}{l}\text { Gene Bank Accession No } \\
\text { (NCBI \& BOLD) }\end{array}$ \\
\hline \multirow[t]{3}{*}{1.} & \multirow[t]{3}{*}{$r b c l$} & \multirow[t]{3}{*}{707} & \multirow[t]{3}{*}{99} & \multirow[t]{3}{*}{99.72} & \multirow[t]{3}{*}{0} & \multirow{3}{*}{$\begin{array}{l}\text { Acmella } \\
\text { paniculata }\end{array}$} & NCBI: OM127877 \\
\hline & & & & & & & BOLD: gi|313770794| \\
\hline & & & & & & & GU724226.1 \\
\hline \multirow[t]{3}{*}{2.} & \multirow[t]{3}{*}{$r b c l$} & \multirow[t]{3}{*}{723} & \multirow[t]{3}{*}{99} & \multirow[t]{3}{*}{99.86} & \multirow[t]{3}{*}{0} & \multirow{3}{*}{$\begin{array}{l}\text { Acmella } \\
\text { radicans }\end{array}$} & NCBI: OM127877 \\
\hline & & & & & & & BOLD: gi|313770795| \\
\hline & & & & & & & GU724226.1 \\
\hline
\end{tabular}

\section{Issr-pcr Analysis:}

There were 113 loci amplified by 15 various ISSR markers with an average of 7.53 loci per primer. Out of the total 113 amplicons, 81 were polymorphic, 43 were monomorphic and 9 were found to be unique showing an average of $60.18 \%$ polymorphism. The number of produced bands by various markers varied from 3 in primer (TC) ${ }_{8} \mathrm{RA}$ to 14 in (AC) 8 YT with a mean amplicon size of 150- 3000 bp (Table 3). The highest number of polymorphic bands (14) was amplified by the primer $(\mathrm{AC})_{8} \mathrm{YT}$, whereas the lowest number of polymorphic bands (3) was obtained with primer $(\mathrm{TC})_{8} \mathrm{RA}$. The primer $(\mathrm{CT})_{8} \mathrm{~T}$ produced a high value (0.65) of polymorphic information content (PIC), while primer (TC) ${ }_{8}$ RA produced a low value (0.21). The resolving power (RP) value of the primers ranged from $5.25\left[(T C)_{8} R A\right]$ to $23.19\left[(A C)_{8} Y T\right]$ with an average of 12.17. Marker index $(\mathrm{MI})$ values of studied primers were reported as low as 0.22 in primer $(\mathrm{TC})_{8} \mathrm{RA}$ and highest value of 0.50 in $(\mathrm{CT})_{8} \mathrm{~T}$ and $(\mathrm{CT})_{9} \mathrm{G}$ with an average of 0.39 . The moderately high average values of \%P, RP, MI, and PIC of ISSR markers analysis advocate the efficiency of the selected markers used for the present investigation. Details of the marker analysis are shown in Table 3. Moreover, the resolution of the selected ISSR primer amplification was found to be good quality as revealed by gel images indicating the usefulness of the markers for this investigation. The obtained results were strongly supported by the proven hypothesis of earlier reports, i.e., ISSR markers are verified as more relevant for assessing the genetic diversity where genome information of the said species is unknown (Bishoyi et al. 2014; Bishoyi et al. 2016a; Gupta et al. 2017). The present study also revealed that occurrence CT/TC repeats are more frequent in A. paniculata genome in comparison to other possible repeats (out of a total of 15 primers, 8 primers are CT/ TC repeats) and these repeats contribute more than $60 \%$ to the total number of amplicons analyzed. This may be due to the more common and random existence of CT/TC repeats in the herbaceous plant genome followed by any other repeats. This result is in agreement with the similar study reported from Allium cultivars (Mishra et al. 2015), Cymbopogon species (Bishoyi et al. 2016) and these repeats are may arbitrarily be distributed in the non-coding region of the genome of a particular species (Lu et al. 2019; Yang et al. 2020; Bhattarai et al. 2021). 
Table 3

Details of ISSR primers used for the study

\begin{tabular}{|c|c|c|c|c|c|c|c|c|c|c|c|}
\hline $\begin{array}{l}\text { Sr. } \\
\text { No. }\end{array}$ & Primer & Sequence $\left(5^{\prime}-3^{\prime}\right)$ & $\begin{array}{l}\text { AFS } \\
\text { (bp) }\end{array}$ & TB & PB & MB & UB & $\% \mathrm{P}$ & RP & MI & $\mathrm{PIC}$ \\
\hline 1 & $(\mathrm{CT})_{8} \mathrm{~T}$ & стстстстстстстстт & $\begin{array}{l}200- \\
1000\end{array}$ & 11 & 6 & 3 & 2 & 54.55 & 10.19 & 0.50 & 0.65 \\
\hline 2 & $(\mathrm{CT})_{8} \mathrm{~A}$ & СТСТСТстстСТСТСТА & $\begin{array}{l}300- \\
900\end{array}$ & 9 & 5 & 4 & 0 & 55.56 & 15.31 & 0.25 & 0.24 \\
\hline 3 & $(\mathrm{CA})_{8} \mathrm{~T}^{\mathrm{N}}$ & CACACACACACACACAT & $\begin{array}{l}400- \\
3000\end{array}$ & 7 & 5 & 2 & 0 & 71.43 & 11.13 & 0.33 & 0.35 \\
\hline 4 & $(\mathrm{TC})_{8} \mathrm{C}$ & тстстстстстстстсс & $\begin{array}{l}350- \\
1000\end{array}$ & 9 & 7 & 2 & 0 & 77.78 & 14.44 & 0.32 & 0.33 \\
\hline 5 & $(\mathrm{AC})_{8} \mathrm{C}$ & ACACACACACACACACC & $\begin{array}{l}500- \\
2000\end{array}$ & 9 & 4 & 5 & 0 & 44.44 & 14.69 & 0.30 & 0.29 \\
\hline 6 & $(G A)_{8} \mathrm{YC}$ & GAGAGAGAGAGAGAGAYC & $\begin{array}{l}150- \\
2000\end{array}$ & 9 & 7 & 2 & 0 & 77.78 & 10.25 & 0.49 & 0.60 \\
\hline 7 & $(\mathrm{CT})_{8} \mathrm{RA}$ & СTСТСТСТСТСТСТСTRA & $\begin{array}{l}200- \\
1000\end{array}$ & 9 & 2 & 6 & 1 & 22.22 & 14.25 & 0.33 & 0.23 \\
\hline 8 & $(\mathrm{CT})_{8} \mathrm{RC}$ & СтстстстСтСTСTСTRC & $\begin{array}{l}250- \\
800\end{array}$ & 5 & 2 & 2 & 1 & 40.00 & 6.31 & 0.47 & 0.45 \\
\hline 9 & $(\mathrm{CA})_{8} \mathrm{RT}$ & CACACACACACACACART & $\begin{array}{l}200- \\
1200\end{array}$ & 10 & 7 & 3 & 0 & 70.00 & 13.50 & 0.44 & 0.44 \\
\hline 10 & $(\mathrm{CA})_{8} \mathrm{RC}$ & CACACACACACACACARC & $\begin{array}{l}250- \\
1200\end{array}$ & 5 & 3 & 1 & 1 & 60.00 & 5.75 & 0.49 & 0.57 \\
\hline 11 & $(\mathrm{TC})_{8} \mathrm{RA}$ & TCTCTCTСTСТСTCTCRA & $\begin{array}{l}600- \\
900\end{array}$ & 3 & 2 & 1 & 0 & 66.67 & 5.25 & 0.22 & 0.21 \\
\hline 12 & $(\mathrm{AC})_{8} \mathrm{YT}$ & ACACACACACACACACYT & $\begin{array}{l}200- \\
3000\end{array}$ & 14 & 10 & 4 & 0 & 71.43 & 23.19 & 0.28 & 0.29 \\
\hline 13 & $(\mathrm{AC})_{8} \mathrm{YG}$ & ACACACACACACACACYG & $\begin{array}{l}250- \\
2000\end{array}$ & 11 & 8 & 3 & 0 & 72.73 & 12.88 & 0.49 & 0.53 \\
\hline 14 & $(\mathrm{CTC})_{6}$ & СтСстсстСстсстССтС & $\begin{array}{l}400- \\
2000\end{array}$ & 11 & 4 & 4 & 3 & 36.36 & 14.06 & 0.46 & 0.43 \\
\hline 15 & $(\mathrm{CT})_{9} \mathrm{G}$ & СТстСТСТСТСТСТСТСТG & $\begin{array}{l}300- \\
900\end{array}$ & 11 & 9 & 1 & 1 & 81.82 & 11.38 & 0.50 & 0.62 \\
\hline Total & & & & 133 & 81 & 43 & 9 & *60.18 & *12.17 & *0.39 & *0.41 \\
\hline
\end{tabular}

\section{Issr Cluster And Genetic Diversity Analysis:}

The ISSR based dendrogram discriminated all the 32 genotypes into two major clusters, i.e., A and B (Figure 2). The first cluster A was further divided into four groups, i.e, sub-cluster Al, All, Alll and AIV. The sub-cluster Al included two genotypes AP1 and AP31 collected from Banaskantha and Valsad respectively. Sub-cluster All has consisted of 15 genotypes, AP3, AP21, AP19, AP28, AP23, AP27, AP8, AP25, AP6, AP16, AP17, AP5, AP10, AP15 and AP7. The sub-cluster Alll included two 
accessions AP13 and AP22 collected from Narmada and Tapi districts, respectively; whose genomic background is from nearby geographic locations. Sub-cluster AIV included only one accession namely, AP20 from Surat district. The highest numbers of genotypes were found to be from sub-cluster All. The second major cluster B was again divided into four subclusters, BI, BII, BIII and BIV. Sub-cluster BI included two genotypes from Banaskantha (AP2) and Bharuch (AP18). The subcluster BII has consisted of six accessions, i.e, AP4, AP26, AP9, AP29, AP14 and AP30. Sub-cluster BIII included three accessions, two (AP11, AP12) from Chota-Udaipur and one (AP32) from Navsari district. The sub-cluster BIV included only one genotype AP24 from Tapi district. All the accessions from Panchmahal district clustered into sub-cluster All only which shows its genetic similarity by virtue of its geographical locations. The clustering patterns of accessions from Banaskantha and Sabarkantha were quite different to our expectations. The accessions were separated into different clusters A and B irrespective of their geographical locations. This indicated its ancestry to the accessions from South Gujarat. It might be due to the anthropogenic movement of plant material of South Gujarat to North Gujarat because of its medicinal and ethnobotanical value.

The Jaccard's similarity coefficients ranged from 0.48 to 0.94 . The highest percentage of similarity ( $94 \%$ ) was found between accessions AP6 and AP16 collected from Rinchhwani, Panchmahal and Chikada, Narmada respectively. The geographical distance between both locations is $193 \mathrm{~km}$ which suggests that both populations might be evolved from the same ancestral population. 93\% similarity was found between accession AP19 from Netrang, Bharuch and accession AP28 from Bhenskatri, Dang. The geographical distance between the two locations is $92 \mathrm{~km}$. Accessions AP2 from Koteshwar, Banaskantha and AP7 from Paniyara, Panchmahal were most distantly related with the similarity value of $48 \%$. The geographical distance between both locations is $212 \mathrm{~km}$. The ISSR based genetic similarity of the studied genotypes is given in Table 4.

The clustering patterns also revealed that accessions from South Gujarat were scattered in all the sub-cluster, which indicated that it might be the ancestor population and site of origin of Acmella paniculta species in Gujarat state. This higher level of diversity among accessions of south Gujarat made them evade more and more possible habitats all over Gujarat, which can also be viewed from their distribution patterns i.e, abundant in South Gujarat which constantly decrease from South to North Gujarat (Figure 2 and Table 4). The genotypes of the hot spots are generally scattered throughout their natural habitats and it has been proved by several researchers using different plant species (Nudin et al. 2017; Bishoyi et al. 2018; Zhou et al. 2020). The present study also revealed that there is no correlation between geographical distance and genetic diversity among the populations of $A$. paniculata. The possible reasons are its center of origin of the plant and anthropogenic activities followed by unrestricted plant material transfer within the geographical boundaries. The obtained results were also supported by similar trend of results are reported in many plant species concerning different geographical locations (Rajendran et al. 2016; Kelkar et al. 2017; Zhou et al. 2020; Venkatesan et al 2021). This type of unrestricted genetic resources migration within and between geographical boundaries may enhance the adaptability of the species in harsh climates leading to the development of better genotypes.

\section{Conclusion}

In the present investigation first and the fruitful attempt has been made to assess genetic diversity among the genotypes of Acmella paniculata collected from Gujarat state using ISSR markers. Clustering analysis of the genotypes revealed that scattering occurrence of genotypes of south Gujarat genotypes in all the sub-clusters. This indicates south Gujarat is the hot spot of Acmella paniculata from where the species has been migrated to other regions of the state and neutralized.

Page 9/14 
The resultant of the study may helpful for germplasm management, conservation of biodiversity and efficient breeding programme management.

\section{Declarations}

\section{Acknowledgement}

The authors are thankful to the Department of Botany, Bioinformatics and Climate Change Impact Management, Gujarat University for providing the necessary facilities for this investigation. We also thanks to HOD of the Botany department, Gujarat University for his encouragement in carrying out this research.

\section{Conflict of interest}

All authors declare that they do not have any conflict of interest.

\section{Author Contributions}

All authors contributed to the study's conception and design. Material preparation, data collection and analysis were performed by Sveta Patel, Nikisha Purohit, Palak Sapra, Archana Mankad, Hitesh Solanki and Ashok Kumar Bishoyi. The first draft of the manuscript was written by Sveta Patel and all authors commented on previous versions of the manuscript. All authors read and approved the final manuscript.

\section{References}

Anderson A, Churchill GA, Autrique JE, Tanksley SD, Sorrells ME (1993). Optimizing parental selection for genetics linkage maps. Genome 36(1):181-186.

Arora S, Vijay S, Kumar D (2011) Phytochemical and antimicrobial studies on the leaves of Spilanthes acmella. J Chem Pharm Res 3(50:145-150

Bhattarai G, Shi A, Kandel DK, Solís-Gracia N, da Silva JA, Avila CA (2021) Genome-wide simple sequence repeats (SSR) markers discovered from whole-genome sequence comparisons of multiple spinach accessions. Sci Rep 11: 9999 , https://doi.org/10.1038/s41598-021-89473-0

Bishoyi AK, Kavane A, Sharma A, Geetha KA (2017) A report on identification of sequence polymorphism in barcode region of six commercially important Cymbopogon species. Mol Bio Rep 44(1):19-24

Bishoyi AK, Kavane A, Sharma A, Geetha KA, Samantaray S, Maiti S (2018) Molecular marker analysis of genetic diversity in relation to reproductive behaviour of Commiphora wightii populations distributed in Gujarat and Rajasthan states of India. S Afr J Bot 117:141-148

Bishoyi AK, Pillai VV, Geetha KA, Maiti S (2014) Assessment of genetic diversity in Clitoria ternatea populations from different parts of India by RAPD and ISSR markers. Genet Resour Crop Evol 61:1597-1609

Bishoyi AK, Sharma A, Kavane A, Geetha KA (2016a) Varietal Discrimination and Genetic Variability analysis of Cymbopogon using RAPD and ISSR Markers Analysis. Appl Biochem Biotechnol 179(4):659-670

Bishoyi, A. K., Kavane, A., Sharma, A., \& Geetha, K. A. (2016b) An efficient DNA isolation protocol for Cymbopogon species suitable for diverse downstream applications. J Appli Hort 18(2):164-168 
Borges-Del-Castillo J, Vazquez-Bueno P, Secundino-Lucas M, Martinez-Martir Al, Joseph-Nathan P (1984) The N-2phenylethylcinnamide from Spilanthes ocymifolia. Phytochemistry 23:2671-2672

Chakraborty A, Devi RKB, Rita S, Singh IT (2002) Local anaesthetic effect of Spilanthes acmella in experimental animal models. Ind J Pharmacol 34:144-145

Chandrasekara CHWMRB, Naranpanawa DNU, Bandusekara BS, Pushpakumara DKNG, Wijesundera DSA, Bandaranayake PCG (2021) Universal barcoding regions, rbcl, matK and trnH-psbA do not discriminate Cinnamomum species in Sri Lanka. PLoS ONE 16(2): e0245592. https://doi.org/10.1371/journal.pone.0245592

Cook CDK (1996) Aquatic and Wetland Plants of India. Oxford University Press, Oxford.; IUCN. 2011. IUCN Red List of Threatened Species (ver. 2011.1)

Enan MR, Palakkott AR, Ksiksi TS (2017) DNA barcoding of selected UAE medicinal plant species: a comparative assessment of herbarium and fresh samples. Physiol Mol Biol Plants 23(1):221-227

Fay MF, Bayer C, Alverson WS, de Bruijn AY, Chase MW (1998) Plastid rbcL sequence data indicate a close affinity between Diegodendron and Bixa. Taxon 47:43-50

Gupta DD, Hui PK, Tag H (2017) Molecular characterization of Acmella paniculata (Asteraceae) from Arunachal Himalayan Region through RAPD and ISSR Markers. J Basic Appl Plant Sci 1(1):105

Hebert PDN, Ratnasingham S, deWaard JR (2003). Barcoding animal life: cytochrome-c oxidase subunit 1 divergences among closely related species. Proc R Soc Bot 270:S96-S99

Ho VT, Tran T, Vu T, Widiarsih S (2021) Comparison of matK and rbc/ DNA barcodes for genetic classification of jewel orchid accessions in Vietnam. Genet Eng Biotechnol 19(1):93.

Jaccard, P (1908) Nouvelles recherches sur la distribution florale. Bull Soc Vaud Sci Nat 44: 223-270

Kelkar VG, Sawardekar SV, Bhave SG, Gokhale NB, Rasam DV, Sawant SS (2017) Analysis of genetic variability among the finger millet germplasm by using ISSR markers. Environ Ecol 35(2C):1233-1237

Kress WJ, Erickson DL (2007) A two-locus global dna barcode for land plants: the coding rbcl gene complements the noncoding trnH-psbA spacer region. PLoS One 2e508

Li H, Xiao W, Tong T (2021) The specific DNA barcodes based on chloroplast genes for species identification of Orchidaceae plants. Sci Rep 11, 1424

Lu Q, Hong Y, Li S, Liu H, Li H, Zhang J, Lan H, Liu H, Li X, Wen S, Zhou G, Varshney RK, Jiang K, Chen X, Liang X (2019) Genome-wide identification of microsatellite markers from cultivated peanut (Arachis hypogaea L.). BMC Genomics 20, 799, https://doi.org/10.1186/s12864-019-6148-5

Mamidala E, Gujjeti RP (2013) Phytochemical and antimicrobial activity of Acmella paniculata plant extracts. J Bio Innov 1:17-22

Mishra P, Kumar LD, Kumar A, Gokul S, Ravikumar K, Shukla A K, Sundaresan V (2015) Population dynamics and conservation implications of Decalepis arayalpathra (J. Joseph and V. Chandras.) Venter., a steno endemic species of Western Ghats, India. App Biochem Biotechnol, 176:1413-1430

Morikawa T, Leggett JM (1990) Isozyme polymorphism in natural populations of Avena canariensis from the Canary Islands. Heredity 64:403-411

Page $11 / 14$ 
Nadeem MA, Nawaz MA, Shahid MQ, Doğan Y, Comertpay G, Yıldız M, Baloch FS (2018) DNA molecular markers in plant breeding: current status and recent advancements in genomic selection and genome editing. Biotechnol Biotechnological Equip 32(2):261-285

Nudin NFH, Ali AM, Ngah N, Mazlan NZ, Mat N, Ghani MNA, Alias N, Zakaria AJ, Jahan MS. ISSR marker-assisted genetic diversity analysis of Dioscorea hispida and selection of the best variety for sustainable production. C R Biol.

2017;340(8):359-66

Nybom H, Bartish I (2000) Effects of life history traits and sampling strategies on genetic diversity estimates obtained with RAPD markers in plants. Perspect Plant Ecol Evol Syst 2(3):93-114

Patel S, Gamit S, Qureshimatva U, Solanki H (2019) Distribution Patterns of Acmella paniculata (Wall. Ex DC.) RK Jansen in Gujarat, India. Int J Res Adv Technolo (7)5:186-191

Paulraj J, Govindarajan R, Palpu P (2013) The genus Spilanthes ethnopharmacology, phytochemistry, and pharmacological properties: a review. Adv Pharmacolo Sci 2013:510298. doi: 10.1155/2013/510298

Powell W, Morgante M, Andre C, Hanafey M, Vogel J, Tingey S, Rafalski A (1996) The comparison of RFLP, RAPD, AFLP and SSR (microsatellite) markers for germplasm analysis. Mol Breed 2(3):225-238

Prevost A, Wilkinson MJ (1999) A new system of comparing PCR primers applied to ISSR fingerprinting of potato cultivars. Theor Appl Genet 98(1):107-112

Rajendran HAD, Muthusamy R, Stanislaus AC, Krishnaraj T, Kuppusamy S, Ignacimuthu S, AIDhabi NA (2016) Analysis of molecular variance and population structure in southern Indian finger millet genotypes using three different molecular markers. J Crop Sci Biotechnol 19:275-283

Rajeshwar Y, Lalitha R (2013) Preliminary phytochemical screening and in vitro anthelmintic effects of Acmella paniculata plant extracts. Biolife 1(3):106-112

Reshmi GR, Rajalaksmi R (2016) Three new combinations in Acmella (Asteraceae: Heliantheae). Trop Plant Res Int J $3(1): 67-69$

Rohlf FJ (1998) NTSYSpc numerical taxonomy and multivariate analysis system version 2.0 user guide.

Sana H, Rani AS, Sulakshana G (2014) Determination of antioxidant potential in Spilanthes acmella using DPPH assay. Int J Curr Microbiol Appl Sci 3:219-223

Saraf DK, Dixit VK (2002) Spilanthes acmella Murr.: study on its extract spilanthol as larvicidal compound. Asian J Exp Sci 16:9-19

Sharma S, Shahzad A, Shahid M Jahan N (2012) An efficient in vitro production of shoots from shoot tips and antifungal activity of Spilanthes acmella (L.) Murr. Int J Plant Dev Bio, 6:40-5

Urankar M, Desai A, Bhat R (2013) Review on medicinal herb genus Spilanthes and Applications in oral hygiene, Universal Journal of Pharmacy 2(6):25-33

Venkatesan J, Ramu V, Sethuraman (2021) Molecular marker for characterization of traditional and hybrid derivatives of Eleusine coracana (L.) using ISSR marker. J Genet Eng Biotechnol https://doi.org/10.1186/s43141-021-00277-1

Yang X, Kalluri UC, Jawdy S, Gunter LE, Yin T, Tschaplinski JT, Weston DJ, Ranjan P, Tuskan GA (2020) The F-Box Gene Family Is Expanded in Herbaceous Annual Plants Relative to Woody Perennial Plants. Plant Physiol 148(3):1189-1200 
Zeitkiewicz E, Rafalski A, Labuda D (1994) Genome fingerprinting by simple sequence repeat (SSR)-anchored polymerase chain reaction amplification. Genomics 20(2):176-183.

Zhou A, Tian P, Li Z (2020) Genetic diversity and differentiation of populations of Chlorops oryzae (Diptera, Chloropidae). BMC Ecol (2020). https://doi.org/10.1186/s12898-020-00293-8

\section{Table}

Table 4 is only available as a download in the Supplemental Files section.

\section{Figures}
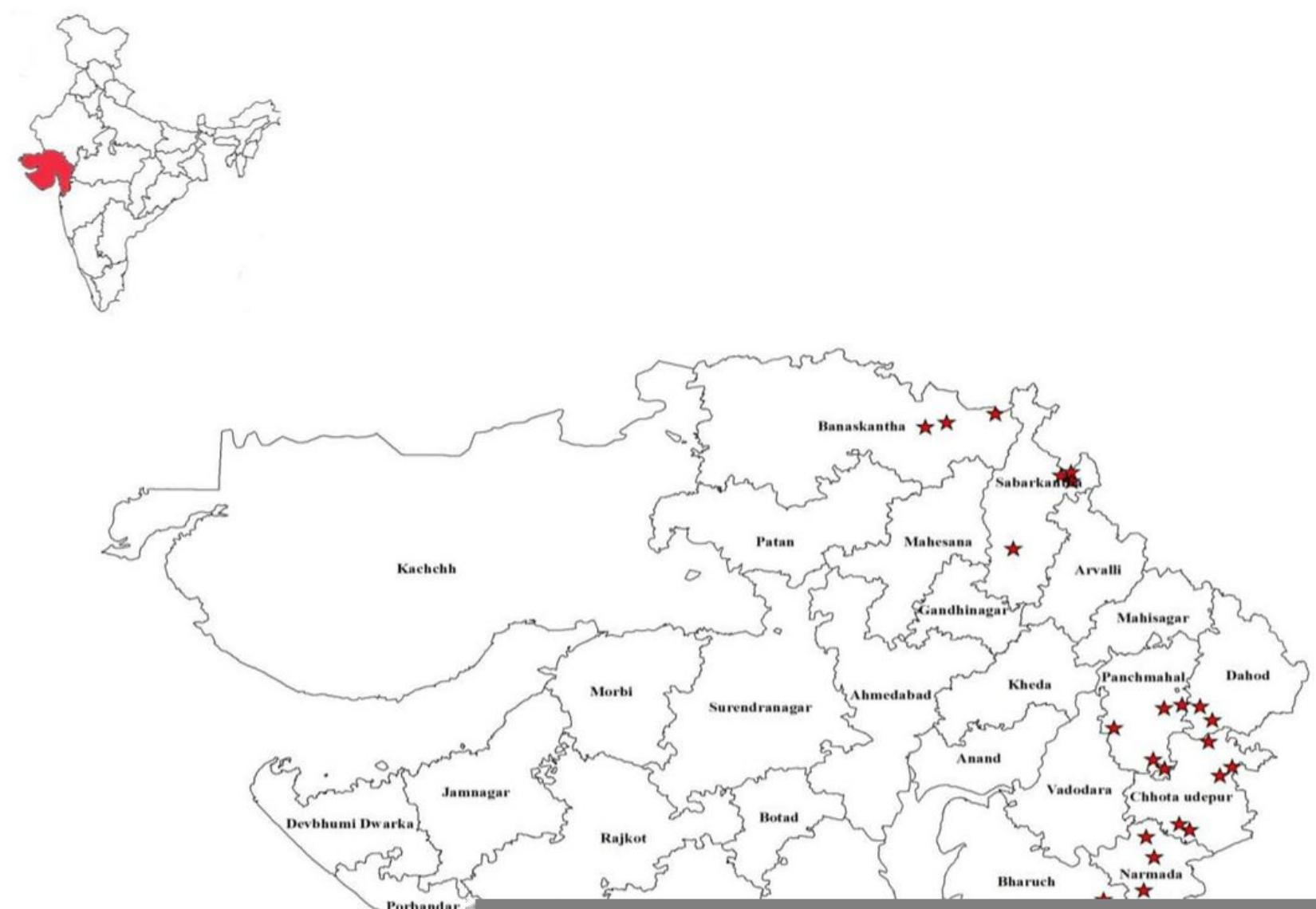

Figure 1 


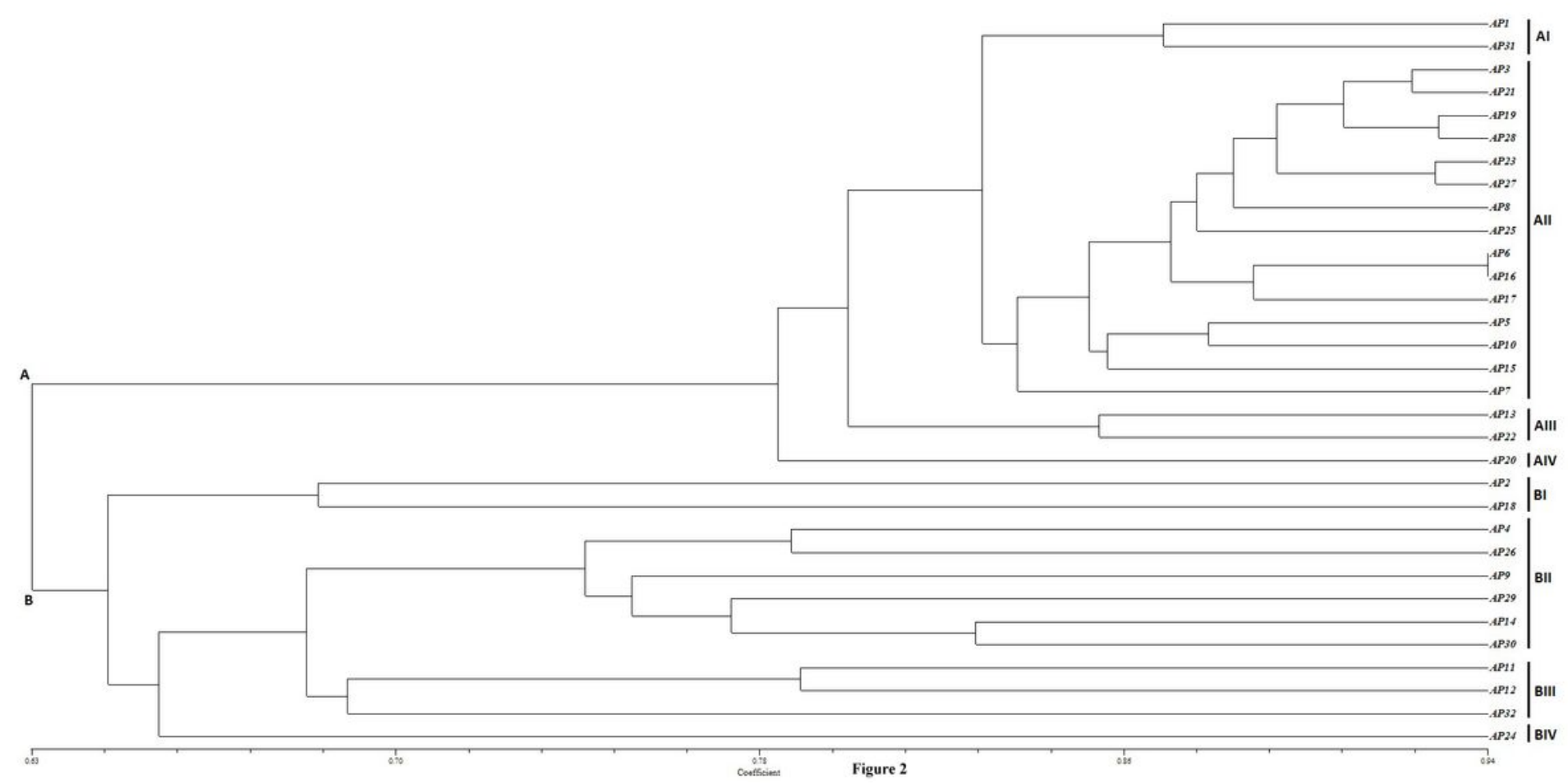

Figure 2

UGPMA Dendrogram with Jaccard's Similarity Coefficient among 32 Accessions of $A$. paniculata based on ISSR Markers

\section{Supplementary Files}

This is a list of supplementary files associated with this preprint. Click to download.

- Table4.docx 